\title{
A KÖNYVTÁROS TUDÁSA ÉS KÉSZSÉGEI A VÁLTOZÓ DIGITÁLIS KÖRÜLMÉNYEK KÖZEPETTE
}

\section{ROSA SAN SEGUNDO}

\section{Tartalmi összefoglaló}

Az az átmenet, amelyet a különbözö információs technológiák alkalmazása fémjelez, lehetövé tette, hogy új módszerekkel férjünk hozzá a kultúrához és tudáshoz a digitális környezetben, ahol egyre nö az igény arra, hogy kezeljük a szemantikusan összekapcsolt hatalmas információmennyiséget. A könyvtáros munkája évezredek alatt alakult ki, és az utóbbi években ez az evolúció alapvetően a technológiai változásokból adódott, de a társadalom változásaiból is, továbbá azokból a követelményekböl, amelyek jelenleg és a jövőben ránk hárulnak. És a jövő még további állandó változatosságot és fejlödést tartogat számunkra.

https://doi.org/10.46280/KOMPKONF.2020.SanSegundo

\section{Bevezetés. Új digitális információs környezet}

Az információ - és az írás - hordozói hatással vannak a kezelésükkel kapcsolatos technikákra, és ezek formálták az emberiség történetének három alapvető korszakát: a szóbeli, az írásbeli és a digitális korszakot.

Történelmünk során három változás zajlott le a tudás megszerzésének módszerében. Az első időszakban szóbeli kommunikáció zajlott; a második az írásbeli kommunikáció meghonosodásával fejlődött ki, lehetővé téve különböző jelek használatát az információk rögzítésére, amelyeket korábban meg kellett jegyezni; ez a nyomdagép feltalálásával bontakozott ki, és olyan, nagy közönség számára tette elérhetővé a könyveket, akik korábban nem fértek hozzá ehhez a forráshoz, s így vált a könyv a tudás jelképévé. A harmadik fázis egy 1980-as években elindult változás következménye, amikor megkezdődött az elektronikus forradalom és az új, elektronikus információhordozók elterjedése. Ebben a három mérföldkőben van valami közös: mindig a tudás átadására kerül sor, miközben írunk és olvasunk. Ezek a tevékenységek általában évszázadokat vettek igénybe, kultúránk forrásait és a tudás átadását testesítik meg. Ugyanakkor az utóbbi években, a harmadik szakaszban a változás hatalmas méreteket öltött; ez a harmadik, digitális korszak az információ új, digitális formátumaiban gyökerezik, szerepel bennük szöveg, képek, hang, és mindegyik új, több szempontból is.

A különböző technológiák révén új módszerekkel férhetünk hozzá a kultúrához és az ismeretekhez, miközben ez sokféleképpen segíti az emberi faj fejlődését. Mint ismeretes, az 
olvasás révén való tanulás miatt módosult az agyunk müködése, a digitális bennszülötteknek pedig már olyan új kognitív készségeik vannak, amelyek meghatározóak, náluk újfajta neuronális szerkezet alakult ki, nyelvi készségekre tettek szert, és újfajta interakcióra léptek a digitális információs technológiákkal. A digitális univerzum új módszereket hozott létre a virtuális valóság érzékelésére, olyan forgatókönyvet, ahol az emlékezet egyre inkább digitális, és az intelligencia egyfajta kollektív platform felé mozdul el. Az új kognitív képességek és technológiák már az új digitális tér gerincét képezik, és mindez azt jelzi, hogy fajunk evolúciójának egyik legnagyobb ugrása kezdetén tartunk.

A digitális korszakban új fogalmi formák merülnek fel, amelyek keretében maga a tudás formátuma és rögzítése hatással van magára a tudásra is, és a digitalizálás nem csupán egy technikai-kulturális lépést jelent. A kultúra, a tudomány és az információ egyre inkább függ majd az új, uralkodó médiumtól, és ebben a helyzetben minden, ami digitális, az valamennyi létrehozott objektumnak a repozitóriuma lesz. Nemcsak az eszköz és a hordozó digitális, hanem a tartalom maga is; így az információszervezésben az anyagi szempont lesz meghatározó. ${ }^{1}$ És mindez digitális környezetben zajlik, ahol még jobban megnő az igény, hogy a hatalmas információmennyiséget kezelni tudjuk. Ez azt jelenti, hogy úffajta, digitális gondolkodás van kialakulóban, amely formálja tapasztalatainkat és azok szerveződési formáját, és ahol az információ megsokszorozódó mennyiségének feldolgozása során a digitálissá vált világban az ismeretelméleti alakzatok kérdései kerülnek napirendre.

\section{A digitális információ technológiai paradigmája}

Az új digitális jelenlét átalakítja a tudományt, annak tartalmát és szervezeti formáit is. Az információtechnológiák határozzák meg gondolkodásmódunkat, cselekedeteinket és életünket; egy új technológiai paradigma jön létre. A tudásszervezésben három modern paradigma jelenlétére lehet következtetni, ezek: ${ }^{2}$ a bibliográfiai paradigma, a pragmatista paradigma és e kettő betetőzése, a technológiai paradigma.

A bibliográfiai paradigma, azaz a pozitivista, bibliográfiai jellegü paradigma vagy a teljesen kiegyenlítő összehasonlítás a 19. és a 20. század terméke. Ez hozta létre a dokumentációs nyelveket, az olyan egyetemes osztályozási rendszereket, mint a Dewey-féle Tizedes Osztályozás, az ETO és mások. A keresés és visszakeresés a hagyományos katalógusokban ugyanígy vagy hasonlóképpen zajlott; ezeknél a kereséseknél a tevékenység inkább az objektumra, mint a szubjektumra összpontosít. Ez a paradigma logikai pozitivizmuson alapul, ahol a keresett, ismeretlen objektum jelenti a prioritást, szemben a szakértöi szubjektummal. Az információkeresésnek ezt az elméleti modelljét, amely csupán a változatlan kiegyenlítésen alapul, bibliográfiai paradigmának hívják, és ma már egyre kevésbé használatos.

SAN SEGUNDO, Rosa; CODINA-CANET, María Adelina 2018. 198-203. p.

2 SAN SEGUNDO, Rosa, 2004. 
A pragmatista paradigma az Egyesült Államokban keletkezett, az amerikai pragmatizmusra építve, és egy új idealista trend ösztönözte, amely szerint az információ visszakeresésének az az alapja, hogy mit tesz a szubjektum. A 20. század elején merült fel olyan politikai, gazdasági és társadalmi körülmények közepette, amelyekre nagyarányú migráció volt jellemző. Ennek során a 19. és a 20. századból származó materialista eszmék, az USA-ban meglévő spiritualizmus és a régi Európa kiterjedt vallásos kontextusa találkozott és olvadt össze egymással. Ebből a konvergenciából eredeztethető a pragmatizmus. Jeles képviselői voltak Charles Pierce, William James és John Dewey, aki filozófusként is müködött. A fogalmi pragmatikus paradigmánál az információkeresési folyamat interaktív folyamat, amely evolúciós, a korábbi teljes kiegyenlítés nélkül. Ember-számítógép paradigmának hívják, mert a szubjektum interakcióban vesz részt. Szubjektívebb fogalom, interaktív, amelyben az amerikai pragmatizmussal átitatott új információkereső nyelvek az információ visszakeresésének új módszereivel foglalkoztak, amelyeket mindig keresztezett a szubjektum, amely az információs technológiákban rejlett, továbbá a századelő ismeretelméleti koncepciójának kontextusában. Itt az információvisszakeresés koncepciójában nincs kiegyenlítés, hanem a keresésben stratégiák szerepelnek és interakció. Ez a visszakeresés szubjektívebb koncepciója. Ez interfészeket hoz létre a használó és a számítógép között, és más, új megközelítéseket az információvisszakeresésben.

Végezetül a technológiai paradigma kontextusa egy olyan világ, mely digitálissá vált, $s$ ahol egy új digitális karakter alakítja át az információt, annak tartalmát és azt is, ahogy meg van szervezve, és amely hatalmas információmennyiség feldolgozásával foglalkozik. Ez új technológiai paradigma, amely olyan gondolkodásmódban, cselekvési és életformában gyökerezik, amely az információtechnológiára alapul. Itt lépünk be visszavonhatatlanul a kognitív rendszerek (szóbeli, írott és digitális) harmadik fázisába, ahol még továbbra is együtt létezünk a korábbi írásos és nyomtatott rendszerekkel, miközben távolodunk is tőlük, s ahol ráadásul a jövőt már döntő módon befolyásolják a digitális bennszülöttek.

A digitális bennszülöttek, a kibersapiensek vagy a poszt-olvasók (az olvasók utódai) másképpen strukturálják az információt, nagyon eltérő a gondolkodásmódjuk, megragadják a digitális emlékezet lehetőségeit. Olyan információszervezési módszert keresnek, amely digitális, ezt diktálják igényeik. Születésüktől fogva a digitális bennszülöttek agyát áthatják az információtechnológiák. Agyuk másképp fejlődik, más módon is dolgozzák fel az információt, mivel birtokolják az ehhez szükséges agyi sebességet.

A digitális bennszülöttek elmentik, besorolják és kezelik a különböző információkat. Azoknak a gyermekeknek az agyát, akik digitális bennszülöttek, akiket a születésüktől kezdve áthatnak az új információs technológiák, másféle fejlődés jellemzi, továbbá másfajta feldolgozási mód, amellyel struktúráikat a végsőkig kihasználják, így valamilyen módon hatással vannak erre az evolúciós folyamatra. Ahogy Danah Boyd mondja, ez nem jelenti azt, hogy ezek az ún. digitális bennszülöttek velük született tudással rendelkeznének a technológiák használatáról, és ne kellene megismerkedniük velük ${ }^{3}$, vagy hogy társadalmi szempont-

3 BOYD, Danah, 2014. 
ból ez lenne a legtermészetesebb vagy legkívánatosabb módja annak, ahogy a gyermekek feldolgozhatják az információkat. Ugyanakkor ma az történik, hogy egy olyan új társadalom jön létre, melyben nem kell bizonyos ismereteket észben tartani, mert ez már nem szükséges a túléléshez. Ez azt jelentheti, hogy megváltozott a reflektálás módja és a gondolkodásmód, amikor az ember nagyobb mennyiségü információt képes feldolgozni, de valószínüleg felületesebben. Ezért a digitális bennszülöttek, miközben alkalmazkodnak környezetükhöz, kevesebb adatot mentenek el, rendszereznek és kezelnek. Ezzel összefüggésben, a fiatalokat az összekapcsoltság korszakában vizsgálva, Dolors Reig megállapítja, hogy a mai fiatalok számára az internet a külső merevlemez szerepét játssza, egy olyan újfajta tárolási memóriáét, amely sok olyan dolgot tárol, amit az embereknek korábban meg kellett jegyezniük ${ }^{4}$. Betsy Sparrow pszichológus azt elemezte, hogy manapság azokat a dolgokat elfelejtjük, amiket megtalálunk az interneten ${ }^{5}$.

A digitális bennszülöttek, a társadalmi túlélési folyamatra válaszolva, olyan új felhasználók, akik újfajta kapcsolatokkal, új szórakozási szokásokkal, tanulmányi feladatokkal, játékokkal stb. rendelkeznek, és kommunikációjuk a számítógépen zajlik. A digitális bennszülöttek generációja úgy élt és úgy nőtt fel, hogy áthatották az új technológiák, életük integráns részét képezik, és sok olyan digitális médiát használnak, amihez hozzáférnek. A térről, időről, identitásukról, emlékezetükről és sok minden másról a technológiai környezetben saját koncepciót alakítottak ki, velük született készségekkel rendelkeznek a nyelvek területén és a digitális környezetben, továbbá új kognitív készségekkel és új neuronális szerkezettel ${ }^{6}$. Az általuk elért információk felépítésének köszönetően hamarabb hoznak döntéseket, több feladatot tudnak egyidejűleg végezni, több dologra figyelnek, ami maga után vonhatja a figyelem lanyhulását, és Elizabeth Cohen ${ }^{7}$ szerint felületesebb a koncentrációjuk.

\section{3. Új információhordozók a digitális könyvtárakban}

A digitális hálózat nagyon másféle eszköz. Úgy mutatja be az információt, mint eddig soha: linkekkel, képekkel, videókkal, fórumokkal, hirdetésekkel és egyéb elemekkel. Ez állandóan töredezetté teszi a figyelmünket és az olvasásunkat. Vannak már újfajta olvasási, írási és a digitális valóság megfigyelésére szolgáló módszerek ; vannak új módszerek arra is, hogyan írjunk a weben. A webes írás radikálisan más feltételeket igényel ahhoz képest, mint amikor hagyományos lineáris nyomtatott szöveget állítunk elő. Más elemeket is figyelembe kell vennünk, ezek: írás, tervezés, nyelv, szöveg, verzió, formátum, a weboldal struktúrája, az információ rétegződése, illusztrációk, idézési módszerek és még sok egyéb. Azok, akik a digitális bennszülöttek közé tartoznak, már másféleképpen viselkednek olvasás közben; az utóbbi

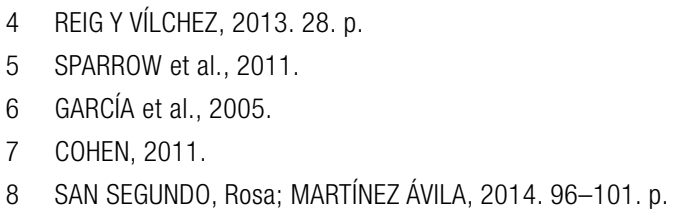


években nagyon megnőtt az e-könyves ipar, ami sok előnnyel is jár és hatalmas átalakulást képvisel az olvasási szokások terén.

García Canclini antropológus és kultúrkritikus elemzi az olvasókat és az internethasználókat ${ }^{9}$ és azt, hogyan viszonyulunk a kulturális örökséghez, a tudáshoz és sok más kontextushoz. Elemzi azt is, mit jelent olvasni, nézőnek lenni, tv-t nézni és a weben szörfölni, és milyen átalakulásokat idéznek elő ezek a tevékenységek. A kiadók és a hírmédia szintén hatalmas változásokon ment át, mivel e két szereplő egymással interakcióban van a digitális konvergencia során. A könyvek, audiovizuális üzenetek és más elektronikus termékek elöállítása új kulturális szokásokat hoz magával, amibe beletartoznak az új kulturált polgárok, az új viszonyok az örökséghez és annak megőrzéséhez, valamint az információszervezés és a hozzáférés új módszerei.

A képernyő az olvasás jövője, mivel újraalkotja az olvasás specifikus jellemzőit: már elektronikus és intertextuális, többféle, közös alkotásra alkalmas, a formátumok és a média interaktivitását és mellérendelö jellegét biztosítja. A könyv koncepcióját kell újra megvizsgálni, elemezni múltját, és elörevetíteni jövőjét, egy olyan jövőt, amelyben mind a formátumok, mind a diskurzus és metafórák, amelyek táplálják, radikálisan átalakulnak. A könyv eltűnése a könyv megszületését is jelenti, valamint a digitális írás-olvasás kezdetét. A publikálás új módszerei nemsokára a hagyományos könyv végét és az olvasás új módszereinek megszületését jelenthetik majd.

A jövőben a tevékenységeknek olyan új körülményekkel kell foglalkozniuk, mivel az olvasáshoz új készségekre van szükség, olyanokra, amelyek a technikailag befolyásolt rendszerek közé tartoznak, amelyekben az olvasókészülékek és módszerek olyan használói magatartást és viselkedést igényelnek, amit meg kell értenünk és amivel dolgoznunk kell. Az e-könyv, az eBook vagy a digitális könyv új eszközöket kíván, az interneten vagy más elektronikus formátumban publikált szövegeket, és e-könyveket támogató eszközöket, azaz különbözö formátumú e-könyvolvasókat.

Mi több, a fejlett e-könyvekben már széles körben vannak videók, audiofájlok, illusztrációk és más multimédiás elemek, és nemcsak arra korlátozódnak, hogy alapvetően reprodukálják a hagyományos könyvet. Sok kiadó, amely technológiai eszközöket használ, lehetővé teszi az ilyen típusú elektronikus könyvek fejlesztését. Példa erre az Epub3 (az a nyílt forráskódú szabvány, amely lehetővé teszi az audió, videó vagy az interaktivitás szerepeltetését), a Fixed Layout (képeket tartalmazó műveknél) vagy a iBooks Author (formátum az Apple eszközeihez, amely képeket videókat, grafikus képeket, 3D-s modelleket, htmL5 animációt, widgeteket tartalmaz) más, gyerekeknek és fiataloknak szóló elektronikus formátumok mellett. Hasonlóképpen emelkedett a digitális hangoskönyvek görbéje az utóbbi években. Az elektronikus kiadványok területe és az őket körülvevő egész ökoszisztéma közötti összekötő kapocs az olvasás-digitalizálás folyamata; vannak olyan országok, ahol az e-könyvek teszik ki az eladások 70\%-át. 
Az új interaktív formátumok az olvasás élményét egész mássá tudják tenni, mint amilyen ma. Jelenleg kutatások folynak a vizualizálás és böngészés új formáinak területén, de az olvasás és a tartalommegosztás területén is, ami lehetővé teszi a használók számára, hogy kollektív észrevételeket és megjegyzéseket tegyenek, különböző eszközökön szinkronizált olvasást szervezzenek, vagy hogy új módszerekkel élvezzék a tájékozódást, egyebek mellett. Ilymódon egy interaktív online könyv nem csak digitális könyv, platformot jelent és igen hasznos. A tudományos áttekintések is hozzájárultak az olvasmányok digitalizálásához, megnyitva ezzel az utat és megszilárdítva a visszavonhatatlan digitális paradigmákat.

A könyvtárakban ma már sokféle típusú formátum és tartalom található. Az információs technológiák bevezetése a könyvtárakban nemcsak a digitális szolgáltatások hozzáférhetőségét jelentette, hanem olyan digitális könyvtárakat is, amelyek az információs technológiákat sokféleképpen használják: a virtuális valóságot, hogy bemutassanak egy interfészt és imitálják a hagyományos könyvtárat, multimédiás technológiát, amely hozzáférést enged nagyszámú digitális gyüjteményhez, és sok egyebet ${ }^{10}$. Tehát nemcsak digitális formátumú gyüjteményekröl vagy tartalmakról van szó. A digitális tartalom egy szükséges komponens, de nem az egyedüli, mivel a digitális hatókör egy jóval tágabb koncepciót takar.

A digitális könyvtár az egyik olyan nagyszabású dolog, amelyet a web tett lehetővé, és egy olyan eszköz is, amely segít abban, hogy egyetemessé tegyük a tudást. Így értelmezve a könyvtár nemcsak egy adatbázis, hanem inkább olyan eszköz, amely megkönnyíti a hozzáférést a világon született lehető legtöbb mü megismeréséhez, akár nyilvános intézményként, akár magánszervezetként, és ez a nagy kihívás.

Lehetségessé vált számunkra, hogy hozzáférjünk a hatalmas mennyiségü digitalizált tudáshoz. A Google, a nagy keresőmotor és tárolóeszköz, megpróbálja digitalizálni a világ összes könyvét; az Európai Uniónak van egy kulturális örökséggel foglalkozó digitális platformja, az Europeana; létezik az UNESCO által szponzorált World Digital Library; és a nagy, világméretü digitális könyvtár, a Mundaneum felé haladunk, amelyröl Otlet és La Fontaine álmodott.

\section{A könyvtáros tudása és készségei}

Az információ változó kontextusa, a tárolás különböző módjai, valamint a valóság eltérő koncepciója a könyvtárosok ismereteinek és készségeinek különböző szakaszait hozta létre a kortárs világban. Az első fázis az 1850-ig terjedő éveket öleli fel, ahol a könyvtáros amatőr tudós volt. A második szakasz 1850-től 1900-ig tart, ekkor kezdődött a szakmaiság új elméletek, technikák és szabályok létrehozásával. A harmadik szakasz 1900 és 1945 közé esik, és ez a könyvtáros-oktató ideje. A negyedik fázis az 1945-1970-es éveket öleli fel, ekkor különülnek el szakmailag a könyvtárosok, a szakkönyvtárosok és a dokumentátorok. Az ötödik szakasz

10 GHANTE, 2011. 187. p. 
1970-től 1990-ig terjed, amikor bekövetkezik a szakma identitásválsága. A hatodik szakasz nagyjából 1990-ben kezdődött az internet, a kibertér és a digitális könyvtárak létrejöttével.

Napjainkban jelentős változás zajlik a szolgáltatásokban; az erőforrások állandó bővülésének a szakaszától egy másikhoz, a stabilitáshoz és új erőforrások és szolgáltatások beépítéséhez jutottunk el. Az információ tulajdonlásának az átadásától az információ hozzáférhetőségéig jutottunk. A könyvtári szolgáltatások egy termékközpontú szervezetből felhasználó-orientált szervezetté alakultak át. Eljutottunk oda, hogy az információ mint köztulajdon mellett elismerjük a kereskedelmi információs szolgálatok létét is. Egy olyan könyvtárból, melyet felkeresnek a felhasználók, olyan könyvtár lett, amely megpróbál közelebb kerülni felhasználóihoz különböző szolgáltatásaival, és az általános szolgáltatások nyújtásától a személyre szabott szolgáltatásokra tér át. Emellett figyelemmel kísérjük az információs műveltséget, a kommunikációt, a metaadatok beillesztését, a különböző szolgáltatások minőségmenedzsmentjét és a Web 2.0 technológiák és eszközök telepítését is ${ }^{11}$.

Egy szakképzett könyvtáros profiljaira tett javaslatnak a könyvtári rendszerben ${ }^{12}$ tekintettel kell lennie a komplexitásra és a változásra. Ugyanakkor vannak bizonyos készségek, melyek állandóak, mint a könyvtár- és információtudomány speciális ismerete; menedzsment- és szervezési készségek, a kommunikációs és információs szolgáltatások ismerete és jártasság a számítógépes eszközök terén.

\subsection{Könyvtár- és információtudományi szaktudás}

A könyvtár- és Információtudományi szakembereknek az információs tudomány speciális ismereteit kell alkalmazniuk a nagy mennyiségü információk és dokumentumok kereséséhez, eléréséhez és használatához, valamint a hagyományos technikai feladatokat, mint a katalogizálás, az osztályozás, az indexelés, a tájékoztatás és a felhasználóképzés, a digitális környezethez igazítva ${ }^{13}$. A feldolgozás felelőse vagy a dokumentumelemző felel a katalógusért és a feldolgozási folyamatért, a szabványosításért, a feldolgozás koordinálásáért, amibe beletartozik a katalogizálás, osztályozás, indexelés feladata, a besorolási adatok ellenőrzése és karbantartása, az ellenőrzött szótárak, összefoglalók, folkszonómiák és mások. Ez a személy felel az állományért és a gyüjteménykezelésért, továbbá dolgozik az információszervezés területén, a keresési rendszerekben, állománygyarapításban, mindezt a digitalizált információ keretein belül, biztosítva azt is, hogy minden interoperábilis legyen. Emellett az intézményi raktározás megszervezése, az intézmény általános vagy tudományos produktumainak elektronikus archívuma, digitálisan tárolva, ahol információcsere-protokollokat kell használnia (Zebra-szervert és OAI-PMH-t vagy még mást használó Z39.50-et). Magukba kell foglalniuk minden folyamat értékelését is, elsősorban a vizuális, digitális és virtuális folyamatokat,

\footnotetext{
SANT-GERONIKOLOU, Stavroula, 2013. 56. p.

12 Consejo de Cooperación Bibliotecaria, 2013.

13 SANT-GERONIKOLOU, Stavroula, 2013. 56. p.
} 
mivel a környezet egyre inkább vizuális jellegü. A képernyőé a jövő, az interaktivitással, valamint a formátumok és a média egymásmellettiségével együtt.

Mindezek a könyvtár- és információtudományi specifikus feladatok kiegészülnek azzal, hogy szükség van olyanokra, akik az információs és dokumentációs ismeretekkel rendelkező személyzetet segítik, de egy alacsonyabb specializációs szinten. Ez tehát a könyvtári asszisztensek vagy a kisegítő személyzet profilja, akik középszintü könyvtárkezelöként tevékenykednek; van még a könyvtár segéd-/kiegészítő személyzete is, akik együttműködnek a könyvtár többi munkatársával minden, a gyüjteménykezeléssel összefüggő folyamatban, a dokumentumokhoz vagy az információkhoz való hozzáférésben, a felhasználónak szóló szolgáltatásokban és egyéb feladatokban.

Nyilvánvaló, hogy a könyvtár- és információtudomány alapjai adják továbbra is a szükséges készségek szilárd alapját. Az információs szakembereknek azonban az információs-dokumentációs speciális ismeretek mellett szükségük van más fontos képességekre is: ilyen az ismeretek frissen tartása, az absztrakció, az elemzés és a szintetizálás, a tudás gyakorlati alkalmazásának és az intézmény vagy szervezet tevékenységei megszervezésének és megtervezésének a képessége, valamint a szociokulturális környezet iránti elkötelezettség. Továbbá készségekkel kell rendelkezniük a szóbeli és írásbeli kommunikáció és az idegen nyelvek területén; az információs és kommunikációs technológiák használatában, elsajátításában és alkalmazásában, a könyvtárral kapcsolatos témákban való kutatás képességével; a különbözö forrásokból származó információk kezelésében; a csapatban vagy önállóan végzett munkában; a problémák azonosításában, felvetésébe és megoldásában; nemcsak folyamatosan és gyorsan kell tanulniuk, hanem olyan új, széles körü személyes és rendszerszemléletü készségeik is kell, hogy legyenek, mint az alkalmazkodás, a kiemelkedö szolgáltatás iránti elkötelezettség, az aktív figyelem, jó csapatszellem, a sokszinüség és a multikulturalizmus elismerése, vállalkozószellem, vezetői gondolkodás, kreativitás és motiváción ${ }^{14}$, ami alapvetően kiegészíti az ágazatban kapott képzést.

\subsection{Vezetési és szervezési készségek}

A digitális információk olyan új készségeket igényelnek kezelésük és szervezésük során, melyek megfelelnek a technológiával működtetett rendszernek, melyben a hozzáférést szolgáló eszközök és formáik olyan felhasználói viselkedést és attitüdöket igényelnek, amelyeket az ilyen fontos feladatot kezelönek ismernie és értenie kell. Az olvasási tapasztalat egy olyan technológiai elemet foglal magában, amely nem akadálya, hanem lehetõsége a 2.0 filozófiának megfelelő új horizontok létrehozásának. Különböző készségekre van szükség, attól függően, hogy milyen típusú könyvtárakról van szó, ahol az információs szakembernek vezetőként kell dolgoznia, megfelelő és használható információs szolgáltatásokat biztosítva.

A könyvtári menedzsment, szervezet és a tervezés a könyvtár típusától függően igen eltérően zajlik, és ez meghatározza a könyvtári személyzet által elvégzendő feladatokat. Tehát

14 SANT-GERONIKOLOU, Stavroula, 2013. 56. p. 
a könyvtárigazgatónak, a könyvtári menedzsernek vagy felügyelőnek műszaki igazgatónak, koordinátornak, valamint a központ vagy szolgálat vezetőjének kell lennie, aki a tervezést irányítja, a célokat kijelöli, az anyagi és az emberi erőforrásokat felügyeli, foglalkozik a belső és külső kapcsolatokkal, figyelembe véve az intézmény célkitüzéseit, legyen az nemzeti vagy regionális könyvtár, egy autonóm régió, egyetem vagy más felsőoktatási intézmény központi könyvtára vagy egy nyilvános könyvtár. Hasonlóképpen, a hálózatot alkotó különböző könyvtárak koordinálásáért vagy együttmüködéséért felelős könyvtárhálózat igazgatójának napra kész stratégiákat kell elővezetnie, összhangban a hálózat könyvtárainak fejlesztéséhez szükséges szervezeti, emberi, képzési és technológiai erőforrásokkal.

Ami az egyszemélyes könyvtárban dolgozó könyvtáros kompetenciáit illeti, függetlenül attól, hogy közkönyvtárban, szakkönyvtárban, iskolában, művészeti iskolában, sportiskolában vagy nyelviskolában dolgozik-e, azoknak átfogóaknak kell lenniük, mivel a könyvtárosnak egyénileg kell az egész könyvtár működtetéséről és az összes alapvető könyvtári funkció végrehajtásáról gondoskodnia. Például az iskolai könyvtáros célja, hogy a könyvtár a tanulók és a tanárok számára a tanulási források elsődleges forrása legyen, és támogassa az iskola oktatási projektjét. Hasonlóképpen, a gyermekeknek és a tizenéveseknek nyújtott szolgáltatások könyvtárosai is felelősek a gyermekek és a fiatal felnőttek részlegeiért, és ott is el kell végezniük a menedzsmenttel és a rendezvényekkel kapcsolatos feladatokat.

Azoknak a könyvtárosoknak, akik egy gyüjteményre vagy felhasználótípusra szakosodnak, függetlenül attól, hogy kormányzati szervekben, kutatóközpontokban, egészségügyi központokban, múzeumokban vagy egyéb kulturális, vallási vagy egyéb intézményben müködnek, egy adott témára vagy felhasználókra összpontosító gyüjteményt kell kezelniük, speciális információforrásokat kell nyújtaniuk ezeknek a speciális felhasználóknak, és stratégiai információforrásokat kell kínálniuk az intézménynek, amelynek dolgoznak. Hasonlóképpen, a régi gyüjtemények könyvtárosának, bibliográfusának, menedzserének a régi kéziratok és gyüjtemények specialistáinak, ősnyomtatvány-szakértőknek, a kulturális örökséghez tartozó gyüjtemények szakértőinek kell lenniük, és ezen gyüjtemények technikai kezelését kell végezniük.

A gyűjtemény kezeléséhez és megszervezéséhez szükséges készségek nem kizárólag a könyvtár vagy a gyüjtemény típusától függenek. A könyvtárosoknak sok más tényezővel kell foglalkozniuk, például a jogi ügyekkel. Itt a jogi ügyekben jártas könyvtárosra van szükség, aki tanácsot tud adni jogi kérdésekben általában, és felügyeli a menedzsmentet, a szerzői jogot, az igazgatás interoperabilitását, a személyzet jogi státuszát, az igazgatási folyamatokat, más intézményekkel kötött megállapodásokat és sok más kérdést. Ezenkívül védeni kell a felhasználók jogait (személyes adataik bizalmas kezelését és adataik védelmét). Az Európai Tanács és az EBLIDA ${ }^{15}$ (European Bureau of Library, Information and Documementation Associations, a Könyvtári, Információs és Dokumentációs Egyesületek Európai Irodája) iránymutatásokat állapít meg; egyesíti azokat a könyvtárosegyesületeket, melyek elősegítik az információhoz való szabad hozzáférést a digitális korban; és munkálkodik a jogalkotás, a

15 EBLIDA, 2014. 
kultúra és az oktatás, a digitalizálás és az online hozzáférés területén az európai keretrendszeren belül. Támogatja azt az elképzelést, hogy garantálni kell mindenki számára a digitális online kiadványok szabad hozzáférését és ingyenes használatát, valamint biztosítani kell azokat a jogi és gazdasági feltételeket, amelyek támogatják az információk tanulmányozását bármilyen formátumban és eszközzel, és azoknak a könyvtárakon keresztül történő terjesztését a társadalom számára. Szintén alapvető jelentőségű a költségvetési feladatok könyvvizsgálójának a szerepe, valamint a döntéshozatalért, a statisztikákért és menedzsment-diagramok elkészítéseért való felelősség minden elfogadott technika alkalmazásával.

\subsection{Információszolgáltatási és kommunikációs ismeretek}

Számos információs szolgáltatás létezik, és ezek alapvető könyvtári feladatok. Ide tartozik a dokumentumforrások kiválasztása és terjesztése; a tanulás támogatása; az általános, középfokú és egyetemi oktatás reformjának támogatása; az információs műveltség oktatása; képzés az információs készségek terén stb. A felhasználóknak biztosított szolgáltatásokat a közszolgálatban jártas szakembernek kell kezelnie, hogy a felhasználók hatékonyan hozzáférhessenek a könyvtár állományához és a kiváló minőségű szolgáltatásokhoz. A felhasználóképzés és az információs műveltség specialistája legyen olyan oktató vagy tréner, aki információhasználatra szakosodott. Az olvasószolgálatban ő segíti és tanítja a felhasználókat, hogy miként használják az információkat különböző eszközök, az állomány és az oktatóprogramok segítségével. Fontos még a szociokulturális ösztönzésre szakosodott könyvtáros is, aki a társadalmi vagy tudományos közösség és mások számára nyújtott szolgáltatásokért felelős; ő a szociokulturális népszerüsítés, a kulturális menedzsment, az olvasás és a társadalmi beilleszkedés szakembere lehet. Aztán van még a tájékoztató könyvtáros, aki az információs és tájékoztató szolgálatra szakosodott.

A tudomány 2.0-t tekintve az alapvető információs szolgáltatások közé tartozik a dokumentumok kiválasztása és forgalmazása, a tanulás és a kutatás támogatása. Ezen kívül foglalkozni kell még a közösségi webes alkalmazások kutatási alkalmazásának nyomon követésével, segíteni a kutatás, a kutatási dokumentumok és eredmények megosztását, és foglalkozni kell más alkalmazásokkal, érdeklődési forrásokkal, blogokkal és egyebekkel. További teendők: tudományos hálózatok, tudós-adatbázisok, kutatási platformok, felmérések, fogalmi térképek létrehozása, fájlok közös használata, bibliográfiai menedzsment, társadalmi jelölők, idézetek indexei, blogok és wikik, tudományos hírek és nyílt hozzáférés. Röviden: elő kell segíteni a tudományos tevékenységben való részvételt, együttmüködést, valamint annak elemzését. Továbbá ajánlásokat kell adni a kutatók számára a szabványosításra és a bibliográfiai hivatkozásokra. Ezen túlmenően a tudomány 2.0 szempontjából nagyon fontos, hogy a kutatási tevékenység értékeléséhez minőségi jelölőket gyüjtsenek, tanácsot adjanak a kutatóknak a publikálási szabványokról, támogassák az online láthatóságot, és megismertessék a kutatások értékelését végző ügynökségek követelményeit, valamint menedzseljék az elektronikus tanulási platformokat a tanárok számára, és kezeljék a nyílt forrású platformokat, a könyvek elektronikus kiadását (az e-könyveket) és beillesszék a metaadatokat. 
A kommunikációs ismereteknél a szükséges intézkedéseknek naprakésznek kell lenniük az új technológiákat illetően. ${ }^{16}$ Ezek a következők: a közösségi web használata, amelynek elő kell mozdítania a virtuális közösségek részvételének és együttmüködésének előmozdítását célzó technológiák fejlesztését; a weboldal információinak frissítése; a weboldalak megtervezése és megszervezése. Továbbá, a közösségi webért felelös könyvtárosnak vagy a közösség vezetöjének ${ }^{17}$ be kell vezetnie és fenn kell tartania különböző web 2.0 alkalmazásokat a könyvtárban, és kezelnie kell a részvételi technológiákat és azokat, amelyek a digitális olvasás bővítését ösztönzik. Az olvasási tapasztalat már egészen másmilyen; már léteznek új módszerek a tartalom vizualizálására, böngészésére, olvasására és megosztására, amelyek lehetővé teszik a felhasználók számára, hogy - többek között - megjegyzéseket és kollektív bejegyzéseket írjanak, szinkronizált olvasást szervezhessenek különböző eszközökön, vagy új módokat élvezhessenek az információk megismerésére. Így a könyvtárosnak olyan közösségi hálózatokat kell népszerüsítenie, amelyeken vélemények, fényképek és a közösség többi tagjával való kommunikáció található, például a MySpace-t, a Facebookot, a Tuentit, a Instagramot stb. Vannak olyan közösségi hálózatok is, amelyek hasznosak különbözö típusú dokumentumok megosztásához és letöltéséhez: ilyen például a Flickr a képekhez, a YouTube a videókhoz és a Google books a könyvek számára. Együttműködésben készült dokumentumok esetén ez a Wiki. Röviden szólva, a könyvtárosnak a közösségi médiát, a blogokat és a wikiket be kell illesztenie a mindennapi rutinba, és képesnek kell lennie, hogy megfelelöen reagáljon azokra a tevékenységekkel kapcsolatos igényekre, melyekhez az oktatástechnológia és a didaktikai tervezés alapszintü ismerete szükséges ${ }^{18}$. Rendelkeznie kell egy olyan világméretű kapcsolat koncepciójával is, amely csatlakozik az összekapcsolt, különböző egyedi intelligenciák globális hálózatához.

\subsection{A számítógépes eszközök ismerete}

A könyvtár számítógépes eszközeit illetően alapvető, hogy legyen egy információs technológiákért vagy a technológiai projektekért felelős szakember, aki megtervezi és megvalósítja a könyvtár technológiai szolgáltatásait és projektjeit, felel a virtuális könyvtárért és a digitális megörzésért, valamint a könyvtár különböző digitális eszközeinek létrehozásáért, kezeléseért és optimalizálásáért; ráadásul specialistája az elektronikus és multimédiás dokumentumoknak, és felel a könyvtár által létrehozott elektronikus dokumentumokért és gondozásukért.

Elengedhetetlenek a technológiai ismeretek és az online digitális kommunikáció, az online csapatmunka, az internethasználók eligazítása, az internetes információmenedzsment, a folyamatos tanulás és a digitális vezetés terén jártas szakember megléte is, aki digitális trendvadás ${ }^{19}$ és egyéb szerepet is betölt. Lényeges követelmény a számítógépes eszközök

16 ESCALONA RÍOS, Lina, 2008. 2. p.

17 HUVILA, Isto; HOLMBERG, Kim; KRONQVIST-BERG, Maria; NIVAKOSKI, Outi; WIDÉN, Gunilla, 2013.

18 SANT-GERONIKOLOU, Stavroula, 2013. 56. p.

19 MARQUINA, Julián, 2016. 22. p. 
ismerete, és ennek a személynek olyan $K+F$ menetrendet kell kialakítania, amely támogatja a technológia, a kísérletezés és az innováció átadását, és értékeli az új technológiák hatását ezek funkcióikra. ${ }^{20}$

A könyvtárakban a jövőben meg kell megvalósítani a virtuális valóság bevezetését vagy a valós világ számítógépes szimulációi használatának a népszerüsítését háromdimenziós képek és elemek révén, hogy a felhasználók a virtuális közegben úgy kommunikálhassanak és mozoghassanak, mintha a való világban lennének. Ez nem csak a könyvekre, hanem a katalógusra és a könyvtár polcaira is alkalmazható. Ide tartozhat a Google-szemüveg használata a világhálón végzett keresés során, képek használatával és a való világra nyomtatott számítógépes adatokkal, ami nem csak a kibővített valóságot tartalamazó könyvekre alkalmazható, hanem más szempontokra is.

Többféle kiemelkedő készségre és ismeretanyagra van szükség. Az információs szakembernek rendelkeznie kell az összes számítógépes eszközzel kapcsolatos elméleti és technikai ismerettel, meg kell tudnia tervezni és le kell bonyolítania projekteket; jelentős számítástechnikai ismeretekkel rendelkeznie ahhoz, hogy technikai támogatást nyújtson a számítógépes rendszerek megvalósításáért felelős csapat bármilyen terjesztési, megőrzési és felülvizsgálati projektjéhez. Ugyanakkor felügyelnie kell az új média, a formátumok, a rendszerek és metaadatok használatát, és döntenie kell arról, mit kell terjeszteni és mit kell megőrizni.

\section{Következtetések}

A könyvtárosok tudásának és készségeinek jelentős mértékben meg kell változni a digitális világban, ami nem könnyü, ahogy erről már szó esett. Az egyéni készségek ${ }^{21}$, amelyeket szoft vagy puha készségnek is nevezünk, növekvő fontossága a technikai ismereteken és készségeken túlmenően megköveteli, hogy a vegyes profilú információs szakemberek (akik nemcsak egy készségkészletet birtokolnak) vagy az információs menedzserek megfeleljenek - a képzés és az aktív részvétel tagadhatatlan igényén túl - a könyvtár 2.0 minden szempontjának és vonatkozásának.

A fontos könyvtáros-szerepnek állandóan fejlődnie kell. Az információ struktúrája már átment a szóbeli és írásbeli szakaszon, és már digitális és szemantikus kölcsönhatást mutat. Korábban az eszköz határozta meg az üzenetet, de ma már úgy tünik, hogy nemcsak a struktúrát határozza meg, hanem magát a valóságot is. A könyvtárosi munka a múlt évezredek alatt sokat fejlődött, és az utóbbi években folytatódott ez a tradíció, alapvetően a technológiai változások, de a társadalom változásai és igényei következtében is. A könyvtári munkában a legfontosabb továbbra is a szolgáltatási készség lesz, perspektívája a változatosság és a fejlődés; a jövője pedig az lesz, hogy az oktatás és a kultúra digitális éllovasává válik. 


\section{Irodalom}

BOYD, Danah: It's complicated. The social lives of networked teens. New Haven, Yale University Press, 2014. $281 \mathrm{p}$.

COHEN, Elizabeth: Does life online give you 'popcorn brain'? 2011. Forrás: http://www.cnn. com/2011/HEALTH/06/23/tech.popcorn.brain.ep/index.html [2018. szeptember 3.]

Competencias profesionales de los bibliotecarios en las universidades andaluzas. 2018. Forrás: https:// www.aab.es/app/download/30258900/AAB-Boletín-115+-+056-124.pdf [2018. szeptember 3.]

EBLIDA: The right to e-read. 2014. Forrás: http://www.eblida.org/News/2014/EBLIDA_E-read_position-paper.pdf [2018.szeptember 3.]

ESCALONA RÍOS, Lina: Hacia el establecimiento del perfil del bibliotecólogo a nivel de Iberoamérica. México, Universidad Nacional Autónoma de México, 2008. 87 p. Forrás: http://libros.metabiblioteca.org/bitstream/001/388/8/978-607-02-0770-9.pdf [2018. szeptember 3.]

GARCIA, Felipe - PORTILLO, Javier - ROMO, Jesús - BENITO, Manuel: Nativos digitales y modelos de aprendizaje. Paris, Universidad de País Vasco. Euskal Herriko Unibertsitatea, 2005. Forrás: http:// spdece07.ehu.es/actas/Garcia.pdf [2018. szeptember 3.]

GARCÍA CANCLINI, Néstor: Lectores, espectadores e internautas. Barcelona, Gedisa, 2007.

GHANTE, P. B.: Skills for librarians in the age of knowledge. = Indian Streams Research Journal, 1. 1. February, 2011. 187-190. p. Forrás: http://citeseerx.ist.psu.edu/viewdoc/download?doi=10.1.1.255.6385\&rep=rep1\&type=pdf [2018. szeptember 3.]

HUVILA, Isto - HOLMBERG, Kim - KRONQVIST-BERG, Maria - NIVAKOSKI, Outi - WIDÉN, Gunilla: What is Librarian 2.0 - New competencies or interactive relations? A library professional viewpoint. $=$ Journal of Librarianship and Information Science, 45. 3. 2013. 198-205. p. Forrás: https://journals.sagepub.com/doi/pdf/10.1177/0961000613477122?casa_token $=$ oBVxPzv_ wF8AAAAA\%3A_shN9mrHBvpAp2dm6CIPEj_Hbo8Ony2SVHQEyjLTbfR6vOliigywwilkQYWKltkJIa2l2PPKl1Q; https://doi.org/10.1177/0961000613477122 [2018. szeptember 3.]

MAGRO MAZO, Carlos: Las bibliotecas, los bibliotecarios, nuevas competencias, nuevas habilidades. Forrás: https://www.aab.es/app/download/22914497/NUEVAS+HABILIDADES.pdf [2018. szeptember 3.]

MARQUINA, Julián: Las competencias digitales en el bibliotecarios actual. = Desiderata, 1. 1. 2016. Forrás: https://www.julianmarquina.es/las-competencias-digitales-que-todos-los-bibliotecariosas-deben-tener/ [2018. szeptember 3.]

MARTÍNEZ USERO, Jose Angel: Nuevas tecnologías para nuevas bibliotecas. Buenos Aires, Alfagrama, 2007.

Perfiles profesionales del sistema Bibliotecario Español: fichas de caracterización. Consejo de Cooperación Bibliotecaria. España. Ministerio de educación, cultura y deporte, 2013. Forrás: http://travesia.mcu. es/portalnb/jspui/bitstream/10421/6841/1/perfilesprofesionalesSBE.pdf [2018. szeptember 3.]

El perfil de competencias de los bibliotecarios de acuerdo a grupos funcionales o de estructura de relación de puestos de trabajo 2015. Universidad de Jaen, 2015. Forrás: https://www.rebiun.org/sites/ default/files/2017-11/IIIPE_Linea4_informe_competencias_REBIUN_2015.pdf [2018. szeptember 3.]

REIG, Dolors - VÍLCHEZ, Luis F.: Los jóvenes en la era de la hiperconectividad: tendencias, claves y miradas. Madrid, Fundación Telefónica, 2013.

SAN SEGUNDO, Rosa: A new conception of representation of knowledge. = Knowledge Organization, 31. 2. 2004. 106-111. p. 
SAN SEGUNDO, Rosa - MARTÍNEZ ÁVILA, Daniel: Digital as a hegemonic medium for epistemology and knowledge organization. In: Babik, Wiesław (ed.): Knowledge organization in the 21st century. Between historical patterns and future prospects. Proceedings of the Thirteenth International ISKO Conference Kraków, Poland. Würzburg, Ergon Verlag, 2014. 96-101. p.

SAN SEGUNDO, Rosa - CODINA-CANET, María Adelina: Epistemological challenges in knowledge organisation in the digital age. In: Ribeiro, Fernanda, Cerveira, Maria Elisa (eds.): Challenges and opportunities for knowledge organization in the digital age. Proceedings of the Fifteenth International ISKO Conference 9-11 July 2018 Porto, Portugal. Würzburg, Ergon Verlag, 198-203. p. Forrás: https://doi.org/10.5771/9783956504211-198 [2018. szeptember3.]

SANT-GERONIKOLOU, Stavroula: Bibliotecario 2.0: Roles y competencias en el nuevo escenario informacional del siglo XXI. Madrid, Universidad Carlos III de Madrid, 2003. Forrás: https://e-archivo. uc3m.es/bitstream/handle/10016/18888/StavroulaSant_TFM_MBSID_2013.pdf [2018. szeptember 3.]

SPARROW, Betsy - LIU, Jenny - WEGNER, Daniel M.: Google effects on memory. Cognitive consequences of having information at our fingertips. = Science, 33. 6043. 2007. 776-778. p.

Forrás: https://doi.org/10.1126/science.1207745 [2018. szeptember 3.]

Rosa San Segundo az Universidad Carlos III de Madrid professzora, 2015-ig a Nemzetközi Tudásszervezési Társaság (International Society for Knowledge Organization, ISKO) Spanish Chapter elnöke, az ISKO Tudományos Tanácsadó Testületének, valamint az ETO Konzorcium Tanácsadó Testületének tagja. Kutatási területei: osztályozási rendszerek, episztemológia, ismeretszervezés és reprezentáció, ETO, a nők részvétele a tudományos életben. A Feminista és Gender Tanulmányok egyetemi platformjának elnöke, a képzés egyik megalapítója a Carlos III de Madrid Egyetemen. A spanyol ETO-kiadások szerkesztője. 